Journal of Philosophy and Culture, Vol. 3, No. 2 June 2006

\title{
CHRISTIAN MISSIONS AND EVOLUTION OF THE CULTURE OF MASS EDUCATION IN WESTERN NIGERIA
}

\author{
S. Ademola Ajayi \\ Department of History, University of Ibadan, Ibadan, Nigeria.
}

\begin{abstract}
The culture of mass education has become an enduring tradition in Western Nigeria. The root of this culture is traceable to the mid-nineteenth century when the Christian missionary bodies began a process of systematic evangelization, using Western education as a medium and an indispensable tool. Early converts were taught how to read the Bible in vernacular - a measure that helped produce the first widespread literate class in Western Nigeria. Thereafter, mass education was promoted through the opening of primary and secondary schools as well as teacher training colleges and trade schools. The pioneering missionary efforts, complemented in later years by the colonial government, received an accelerated boost, reaching a peak in the mid-1950s during the era of internal self-rule when the Western Nigerian government introduced the Free Education Programme in the region. In spite of the termination of the government that introduced the Free Education Scheme following the military take-over in 1966, the rising trend of popular education continued unabated. Military and civilian governments alike have, ever since, remained committed to mass education such that popular Education remains to this day, the greatest industry in Western Nigeria. The contention in this Paper is that the culture of mass education in Western Nigeria, even to this day, and in spite of occasional modifications, is a logical conclusion to an established culture of mass education, the root of which is traceable to the Christian missionary era. The paper concludes with an analysis of the impact, which the various phases of the evolutionary process have
\end{abstract}




\section{S. Ademola Ajayi}

made on the history of education in Western Nigeria in particular, and the country as a whole.

\section{Introduction}

The genesis of Western education in western Nigeria ${ }^{1}$ could be traced to the era of the Christian missionaries who had established contacts with this part of the country as early as the $15^{\text {th }}$ century. This early effort began with the Portuguese who ventured into the coastal areas in about 1472. ${ }^{2}$ Indeed, the Portuguese missionaries operated in the kingdom of Benin between 1515 and 1538 at the invitation of the $\mathrm{Oba}$ of Benin. ${ }^{3}$ However, these early efforts in the area failed completely to displace the traditional religion. Though the Portuguese missionaries achieved some measure of success in Warri where, from the $1570 \mathrm{~s}$, they began to make considerable impact on the $\mathrm{Olu}^{4}$, that is, the paramount ruler of Warri, this early missionary effort did not endure. For, in spite of the fact that the religion operated there for about a century or more, it never spread beyond the court. Even at the court, true Christianity was confined to the king and princes as well as the sons of important chiefs. The others merely paid lip services to the religion in order to please the king. ${ }^{5}$ Consequently, at the end of the $18^{\text {th }}$ century, the missionary efforts of evangelism in Western Nigeria had failed. The only impact was that a few citizens had their secular lives influenced to some extent by European ways and that was because of economic, political and social advantages. On the majority of the populace, they could not make any impact. 


\section{Christian Missions and Evolution of Mass Education}

\section{The Re-awakening of Christian Missionary Enterprise in the $19^{\text {th }}$ Century}

By the beginning of the $19^{\text {th }}$ century, there was a new missionary zeal to evangelize not only Western Nigeria but the entire country - this time with a determination to succeed. It was, indeed, an attempt to evangelize beyond the court. As rightly demonstrated by Professor J.F. Ade Ajayi, what gave evangelization so much strength to succeed in Western Nigeria, as in other parts of West Africa, during this era of reawakening was its close association with the anti-slavery movement. ${ }^{6}$ It was believed by the Humanitarians and the Philosophers of the Age of Reason that the solution to the teething problem of abolition of the obnoxious trans-Atlantic slave trade, was to be found partly in Christianity which it was hoped would open the minds and eyes of the people to see the evils of the nefarious trade. ${ }^{7}$

At any rate, enduring and successful missionary activity in Western Nigeria in the $19^{\text {th }}$ century began in Yorubaland. Consequent upon the anti-slave trade and anti-slavery abolitionist acts of 1807 and 1833 respectively, many freed slaves of Yoruba origin returned from Freetown to Badagry, Lagos and Abeokuta in the 1830s. In fact by $1842,{ }^{9}$ no less than five hundred Christianized liberated slaves from Sierra Leone had settled in Abeokuta alone. They it was, who appealed to the Church Missionary Society (C.M.S.) in Sierra Leone for missionaries to work among them. Consequent upon their appeal, therefore, the C.M.S. began to establish missions in Yorubaland. This effort began in 1841 when two C.M.S. missionaries - the Rev. J.F. Schon and Samuel Ajayi Crowther (later to become the first African Bishop of the C.M.S.) 


\section{S. Ademola Ajayi}

accompanied the 1841 Niger expedition. In 1846, Henry Townsend of the C.M.S. established a resident mission at Abeokuta with Revd Samuel Ajayi Crowther (ordained in 1843) as one of his helpers. It was from here that the C.M.S. expanded to other Yoruba towns notably Lagos (1852), Ibadan (1853) and Oyo (1856). Other missionary bodies, which followed suit, were the Methodist Mission, which established at Badagry and Abeokuta in 1842 and 1848 respectively, as well as the Baptist Mission with its base in Ijaye and Ogbomoso where it established Missions in 1852 and 1855 respectively. The consequence of this missionary enterprise in Western Nigeria was the eventual European influence in all aspects of life - religions, economic, social and political. Their greatest and perhaps most spectacular achievement and influence, and far more relevant to our discussion, was in the educational sphere.

\section{Christian Missions and the Introduction of Western Education}

It is a fact of common knowledge that among Christian missions, education and evangelization were inseparable. As it was the objective of the early Christian missionaries to convert the 'heathen' or the benighted Africans to Christianity via western education, this was promoted right from the beginning. Even though the various missions adopted different approaches to the implementation of their policies, they all regarded literacy education as an indispensable tool in the course of evangelization. It was due largely to their singular contribution in this respect, which inspired a writer to remark that 'of all the agents of imperialism, it was the missionary who made the most revolutionary demand on the Nigerians'. "11 Yet it should 


\section{Christian Missions and Evolution of Mass Education}

be grasped that missionary education was designed to aid religion - to enable converts to read and have greater understanding of the Bible. But even then, parents favoured the schools established more than the religion because of the opportunity of learning useful skills such as reading and writing of English and Portuguese, Arithmetic etc which the schools provided.

The first contribution of the missionaries towards the development of western education in Western Nigeria was the linguistic study and reduction to writing of the two major languages - Yoruba and Edo - and the translation of the Bible into these languages. Samuel Ajayi Crowther of the C.M.S. was foremost in reducing the Yoruba language to writing and he pioneered the translation of several books of the Bible into that language. The pioneer Baptist missionary to this area, the Revd Thomas Jefferson Bowen, spent the first 18 months of his missionary career sojourning in Abeokuta where he studied the Yoruba language. The end result was his production of a Grammar and Dictionary of the Yoruba Language in $1858^{11}$. By the mid-nineteenth century, therefore, the language had grammar books and dictionaries. In this way the missionaries were able to teach their converts how to read the Bible in vernacular and thus produced the first widespread literate class in Western Nigeria. To further promote the study of these languages, some of the missionaries established printing presses with which they published newspapers. The Revd Henry Townsend was said to have brought the first printing press to Nigeria in 1852 and started the first Yoruba Newspaper in the country - the Iwe Irohin in $1859 .{ }^{\mathbf{1 2}}$ That journal, published fortnightly, was not only a news bulletin to 


\section{S. Ademola Ajayi}

church and state, but helped to educate the growing reading public through didactic essays in the areas of history and politics. ${ }^{13}$

Closely connected with their literacy development of the indigenous languages was their other contribution namely, the promotion of education through the opening of primary and secondary schools as well as training colleges for the training of teachers, and trade schools for the training of craftsmen. While the Methodists should be credited with establishing the first school in this part of the country, it was the C.M.S. Mission that was to make the most important contribution to education in the early period.

The various missions also established hundreds of primary schools for boys and girls all over Western Nigeria. As this writer has demonstrated elsewhere, ${ }^{14}$ consequent on the missionary venture, over $95 \%$ of the schools in Western Nigeria were, as late as 1945, owned by Christian Missions. By the same token, no less than $97 \%$ of the pupils/students of school age were attending these mission schools during the same period. From all available evidences then, the Christians missions have, not only charted the course of Western education in Western Nigeria but have as well laid a firm foundation for mass education on which later agencies built.

Colonial Rule and the Expansion in the Scope and Structure of Western Education:

From the closing years of the $19^{\text {th }}$ century down to the beginning of the $20^{\text {th }}$ century and afterwards, the colonial government assisted in building on the foundations laid in the previous century by the missionary bodies. The activities of the colonial government in the area of western education not only in Western Nigeria but in the country as a whole are 


\section{Christian Missions and Evolution of Mass Education}

extensively covered in existing literature. ${ }^{15}$ It would be superfluous, therefore, to tread over this familiar ground in any details. Nonetheless, certain salient features of the colonial education in this part of the country should be re-echoed in order to enrich our understanding of the significance of that era in the course of the evolution of the culture of mass education in Western Nigeria.

To a very large extent, the colonial government treated education with relatively less importance and never accorded it the due priority it deserved. So haphazard were the priorities of that government that education received attention only 'after the building of prisons and police barracks'. ${ }^{16}$ This lukewarm attitude towards the education of the citizenry was not confined to Western Nigeria. That was the general trend in colonial Nigeria. For instance, an editorial comment in an issue of the Lagos Times in 1881 condemned in no mean terms, Government's approval of $£ 16,000$ for the construction of a gaol house to the relative neglect of education. ${ }^{17}$ To worsen matters, however, a comparative analogy showed the $£ 1,000$ proposed for education in 1872 was later reduced to $£ 330$ and eventually only $£ 30$ was spent on education that year. ${ }^{18}$ This trend should, however, not be too surprising. For, as aptly demonstrated by Osoba and Fajana,

The primary consideration of the British administration set up in the Niger Delta and Yorubaland between 1885 and 1900 and which along with the Lagos Colony, were crystallized into the Colony and Protectorate of Southern Nigeria in 1906, was to establish an effective British presence in these areas at minimum cost to the British tax-payer. This meant in effect that initially and for long, the colonial administration placed the emphasis on military and diplomatic campaigns among 


\section{S. Ademola Ajayi}

the people while giving the advancement of education a low priority and perfunctory attention. ${ }^{19}$

Thus, the colonial administration could not achieve as much improvement of the educational system, above that which they inherited from the missionaries. The British officials were more guided by consideration of effective colonial administrative control, consequent upon which they had a myopic view of education and portrayed (or perhaps betrayed) the traditional colonial government's stringiness in financing the education of their subjects. In a nutshell, government intervention in educational development was ineffective initially, at least up to the second decade of the $20^{\text {th }}$ century. Even after this period, education remained restricted both in scope and in quality to the base level requirement of the regime, and was structured in such a way as not to constitute a challenge to the hegemony of the imperial order. In the circumstance, education in Western Nigeria up to the era of internal self-rule in the area was neither free nor universal. So grave was the situation that parents, guardians and relatives had to make great sacrifices to see that their wards got as much education as they could afford, for this was the royal road to a well paid job.

Whatever the myopia of the British colonial educational policies when compared with the Christian Missionary venture, it is difficult to deny completely the fact that in their own little way, the British authorities did contribute in building on the foundation of mass educational culture, which the missionary societies had earlier laid. Both agencies, therefore, helped to soften the ground for mass popular education in later years. 


\section{Christian Missions and Evolution of Mass Education}

\section{The Era of Self Determination in Education, 1950 Onwards}

The 1950s witnessed an exemplary innovation in the history of education in Nigeria. This period, which could aptly be described as a revolutionary era, saw the introduction of the Free Education scheme in the then Western region, and marked a radical departure from the hitherto existing educational structure not only in Western Nigeria, but the country as a whole. Following the adoption of a Federal constitution in 1951, well known as the McPherson's Constitution, the legislative houses so created in the three regions, that is Northern, Eastern and Western regions, were empowered to make laws with respect to certain enumerated subjects including education. ${ }^{\mathbf{2 0}}$ With this development, responsibility for education, at the regional level, devolved on the governments of the respective regions while the Federal Ministry of Education took charge of education in the Federal Territory of Lagos.

The Western regional government headed by the Action Group placed its highest priority on education. No sooner had the party won the first election to the regional House of Assembly in July 1952, than its leader, Chief Obafemi Awolowo, ${ }^{21}$ made it clear in his first budget speech, that his government would give top priority to education, among other programmes, as far as that budget would allow. As he spelled out in later years, “... as far as possible, expenditure on services which tend to the welfare and health and education of the people should be increased at the expense of any expenditure that does not answer to the same test". ${ }^{22}$ In July of the same year (1952), the Minister of Education for the Western Region, Chief S.O. Awokoya, presented a 


\section{S. Ademola Ajayi}

comprehensive set of proposals calling for a free, universal and compulsory education otherwise known as the Universal Primary Education (U.P.E.) for the Western Region by January $1955 .{ }^{23}$ In the view of Awokoya, these proposals deserved utmost priority. For according to him,

Educational development is imperative and urgent. It must be treated as a national emergency, second only to war. It must move with the momentum of a revolution. Our past history makes it a matter of paramount necessity to catch up with the rest of the world. Our present position makes it obligatory to reorientate our policy and formulate certain major principles, which must determine the nature of our institutional proposals. ${ }^{24}$

This was the prelude to the birth of what Babs Fafunwa has aptly described as "the boldest, and perhaps the most unprecedented educational scheme in Africa south of the Sahara", ${ }^{25}$ as an ample demonstration of the Western Regional government's whole-hearted commitment to the vital interest of her subjects. "The launching of this scheme", says Adewumi Fajana, "was a milestone in the educational history of Nigeria". ${ }^{26}$

A remarkable feature of the educational system of this era was the rapid numerical growth of schools at all levels primary, secondary (Modern and Grammar) as well as tertiary. Teacher-training institutions were equally expanded - all with the aim of translating the proposals of the government into a concrete reality. The greatest expansion of this period was at the primary school level. Thus the number of primary schools rose from 3,550 in 1952 to 6,274 by the end of $1954 .{ }^{27}$ By 1955, the figure had risen to 6,407 (see Table 1 below). At the same period, as many as 8,239 new classrooms were added to 


\section{Christian Missions and Evolution of Mass Education}

the existing schools while 9,450 new classrooms were provided for the completely new schools. ${ }^{28}$ By the end of 1958, the number of primary schools had risen as high as 6,670 (Table 1). The general trend of expansion of primary school during the first phase of this era is well illustrated in Table 1.

TABLE 1

Number Of Schools In The Western Region By Type, 1954 - 1960

\begin{tabular}{|l|l|l|l|l|l|l|l|}
\hline Type of School & $\mathbf{1 9 5 4}$ & $\mathbf{1 9 5 5}$ & $\mathbf{1 9 5 6}$ & $\mathbf{1 9 5 7}$ & $\mathbf{1 9 5 8}$ & $\mathbf{1 9 5 8}$ & $\mathbf{1 9 6 0}$ \\
\hline Primary & $*$ & 6,407 & 6,603 & 6,628 & 6,670 & 6,518 & 6,450 \\
\hline Sec. Modern & 9 & 180 & $106+$ & 254 & 262 & 420 & 533 \\
\hline Sec. Grammar & 59 & 73 & 91 & 108 & 177 & 138 & 167 \\
\hline Grade III T. T. & 42 & 59 & 69 & 71 & $70++$ & 67 & 69 \\
\hline Grade II T. T. & 21 & 25 & 27 & 27 & 28 & 30 & 31 \\
\hline Voc. Schools & - & - & - & 2 & 2 & 2 & 5 \\
\hline
\end{tabular}

Note: * Accurate Figures not known

+ Reduction in 1955 figures due to consolidation of a number of schools.

++ Baptist, Idi-Aba closed and students moved to Baptist, Ife.

Source: Compiled from Western Region of Nigeria, Annual Abstract of Education Statistics, 1953-58 \& 1955-60 respectively. (Ibadan: Ministry of Economic Planning and Community Development, Statistical Division, June 1959 \& September, 1961 respectively), p. 7

TABLE 2

Number Of Schools In The Western Region By Type 1961-66

\begin{tabular}{|l|l|l|l|l|l|l|}
\hline Type of School & $\mathbf{1 9 6 1}$ & $\mathbf{1 9 6 2}$ & $\mathbf{1 9 6 3}$ & $\mathbf{1 9 6 5}$ & $\mathbf{1 9 6 5}$ & $\mathbf{1 9 6 6}$ \\
\hline Primary & 6,468 & 6,420 & 6,311 & 4,375 & 4,364 & 4,340 \\
\hline Secondary Modern & 586 & 666 & 699 & 459 & 441 & 394 \\
\hline $\begin{array}{l}\text { Secondary } \\
\text { Grammar }\end{array}$ & 177 & 189 & 212 & 174 & 195 & 206 \\
\hline Grade III T. T. & 69 & 69 & 53 & 38 & - & - \\
\hline Grade II T. T. & 33 & 36 & 35 & 30 & 33 & 31 \\
\hline $\begin{array}{l}\text { Grade I Rural Sc } \\
\text { T.T. }\end{array}$ & - & - & 1 & 1 & 1 & - \\
\hline Advanced T. T. & - & - & 2 & 3 & 2 & 2 \\
\hline Voc: Trade Centres & 4 & 5 & $5^{*}$ & 5 & 5 & 5 \\
\hline $\begin{array}{l}\text { Junior High } \\
\text { Schools }\end{array}$ & - & - & - & - & 6 & 6 \\
\hline Technical Institutes & - & - & 1 & 1 & 1 & 1 \\
\hline Sch. for Handicapd & - & - & 2 & 3 & 3 & 3 \\
\hline Special Schools & & & - & - & - & 23 \\
\hline
\end{tabular}




\section{S. Ademola Ajayi}

* Excluding Trade Centre, Sapele.

Source: Compiled from Western Nigeria Annual Abstract of Education Statistics, 1961-1966 (Ibadan, Ministry of Economic Planning and Community (Later Social) Development (Statistics Division, 1961-67)

In 1963, the Mid-west region was carved out of the old Western region. This explains why there was a reduction in the number of schools thereafter (compare the 1963 and 1964 figures above). Following the creation of the Mid-west region, therefore, the Statistics Division of the Ministry of Economic Planning and Community Development prepared a new statistics, details of which are provided by this writer elsewhere (see Ajayi, 1984:48).

Be that as it may, even though the real intention of the regional government was to provide free primary education for all eligible pupils, the development of the scheme was not limited to this level of education. In practical terms, primary education was not developed in isolation. It was viewed as a means to an end and not an end in itself; other levels of education were seen as part and parcel of a broad scheme. The purpose of the government is well summarized in Awokoya's proposal:

The main purpose of policy for the next four years may be simply stated as one of expansion and re-orientation. This implies an all-out expansion of all types of educational institutions. It connotes an increase in the number of primary schools, the inauguration of a number of training colleges, and the creation of technical institutes and commercial academics... ${ }^{30}$

Thus, side by side with the expansion in primary schools, there were similar provisions for secondary and 


\section{Christian Missions and Evolution of Mass Education}

technical education, which were equally boosted. This is quite logical bearing in mind the fact that the bulk of the educated manpower required for the administrative, commercial and industrial services in the region, would be drawn from the products of the secondary and technical institutions. As a matter of fact, by the beginning of the free and universal education period, the demand for the products of secondary schools was as great as the provision of secondary education was scarce.

A corollary to the increase in the number of schools was the rapid numerical growth in school population at all levels of education. In 1952 when Awokoya presented his proposal before the Western House of Assembly, the number of children at school in the Western region then was $381,000 .^{31}$ The total number of children of school age by then was estimated at $1,146,000 .^{32}$ Going by this estimate, the number of children not at school therefore was about 765,000.

During the first six years of Free Universal Primary Education, there were increase in both boys' and girls' enrolment. This was to be expected though not to the extent to which it did occur. ${ }^{33}$ In 1954, 456,600 pupils were attending fee paying primary schools in the West but when the scheme was launched in January 1955, 811,432 children turned up (see Table 3) making an increase of 354,832 over the figure of the enrolment for the previous year. These figures represented a jump from 35 percent to 61 percent of the 5-14 year olds. ${ }^{34}$ That same Table 3 shows that by 1958 over one million children were enrolled. 


\section{S. Ademola Ajayi}

TABLE 3

Enrolment In Primary Schools In The Western Region By Sex, 1953-1966

\begin{tabular}{|l|l|l|l|l|l|}
\hline Year & Boys & Girls & Total & $\begin{array}{l}\text { Increase Over } \\
\text { Previous Year }\end{array}$ & $\begin{array}{l}\text { Percentage } \\
\text { Change }\end{array}$ \\
\hline 1953 & 320,542 & 109,000 & 429,542 & - & - \\
\hline 1954 & 340,610 & 115,990 & 456,600 & 27,058 & 6.30 \\
\hline 1955 & 536,676 & 274,756 & 811,432 & 354,832 & 77.71 \\
\hline 1956 & 583,688 & 324,334 & 908,022 & 96,590 & 11.99 \\
\hline 1957 & 619,577 & 363,178 & 982,755 & 74,733 & 8.23 \\
\hline 1958 & 642,856 & 394,532 & $1,037,388$ & 54,644 & 5.56 \\
\hline 1959 & 665,442 & 414,861 & $1,080,303$ & 42,915 & 4.14 \\
\hline 1960 & 687,215 & 437,573 & $1,124,788$ & 44,485 & 4.12 \\
\hline 1961 & 677,009 & 454,400 & $1,131,409$ & 6,621 & 0.59 \\
\hline 1962 & 656,551 & 452,448 & $1,109,999$ & $-22,410$ (decrease) & -1.98 \\
\hline $1963 \mathrm{a}$. & 643,826 & 455,592 & $1,099,418$ & $-9,581$ (decrease) & -0.86 \\
\hline $1963 \mathrm{~b}$. & $(433,075)$ & $(296,472)$ & $(729,547)$ & $-6,776$ (decrease) & -0.62 \\
\hline 1964 & 435,399 & 297,771 & 733,170 & 3,623 & 0.50 \\
\hline 1965 & 438,184 & 298,964 & 737,148 & 3,978 & 0.54 \\
\hline 1966 & 440,991 & 300,006 & 740,997 & 3,849 & 0.52 \\
\hline
\end{tabular}

+N.B. Figures in bracket are the new ones prepared by the Statistics Division of the Ministry of Planning and Community Development after the carving out of the Mid-West region in 1963

Source: Compiled from the Annual Abstract of Education Statistics, 1954-66 (Ibadan, Ministry of Economic Planning and Community Development, Statistics Division).

Before rounding off, it should be stressed that the Western region was so committed to the provision of mass education for her citizenry that education gulped the lion share of governmental expenditure. Between the years 1955-1966, for instance, education attracted the largest share of the Region's recurrent budget having varied between $28.9 \%$ and $41.2 \%$ during the period (see Table 4 ). 


\section{Christian Missions and Evolution of Mass Education}

TABLE 4

Comparison Of Recurrent Education Budget With The Regional Budget, 1954-66

\begin{tabular}{|l|l|l|l|}
\hline Year & $\begin{array}{l}\text { Actual Education } \\
\text { Recurrent } \\
\text { Budget }\end{array}$ & $\begin{array}{l}\text { Actual Regional } \\
\text { Recurrent Budget }\end{array}$ & $\begin{array}{l}\text { Education as \% } \\
\text { of Regional }\end{array}$ \\
\hline $1954-55$ & $£$ & $£$ & $£$ \\
\hline $1955-56$ & $3,806,745$ & $9,283,690$ & 41.0 \\
\hline $1956-57$ & $4,873,305$ & $11,366,931$ & 34.0 \\
\hline $1957-58$ & $5,496,201$ & $15,522,128$ & 28.9 \\
\hline $1958-59$ & $5,616,687$ & $14,288,000$ & 38.5 \\
\hline $1959-60$ & $7,161,303$ & $13,604,163$ & 41.2 \\
\hline $1960-61$ & $8,773,325$ & $22,152,351$ & 32.3 \\
\hline $1961-62$ & $8,548,829$ & $22,769,880$ & 38.5 \\
\hline $1962-63$ & $8,891,921$ & $21,798,923$ & 39.2 \\
\hline $1963-64$ & $6,206,949$ & $24,948,913$ & 35.6 \\
\hline$* 1964-65$ & $6,554,640$ & $18,191,071$ & 34.1 \\
\hline$* 1965-66$ & $7,048,530$ & $16,946,310$ & 38.6 \\
\hline
\end{tabular}

* Government Approved Estimated Expenditure.

Source: Some Trends in Education in the Western Region of Nigeria, 1955-65 (Pilot Project for Rural Employment Promotion (International Labour Office, Mission, Ibadan, Western Nigeria, October, 1965), p. 17.

In 1958 , for instance, $41.2 \%$ was devoted to education alone. This undoubtedly represented one of the highest proportional expenditures on education the world over. This was an ample demonstration of the great importance, which the regional government placed upon education.

\section{Concluding Remarks}

That the government of Western Nigeria opted for a free and universal education during the period of transition from colonial rule in the 1950s up to the post independence era is a logical conclusion to an established culture of mass education whose roots could be traced to the era of Christian Missionary enterprise in the area. It is true that the climate of 


\section{S. Ademola Ajayi}

the 1950s favoured the introduction of a mass education programme. However, as this writer has analyzed extensively elsewhere, ${ }^{35}$ there were such other influences as the United Nation's 1948 Declaration of Human rights which asserted, among other things, the rights of individuals to Free Education; the neighboring Gold Coast (Ghana) example; favourable economic climate vis-à-vis the relative availability of abundant human and material resources to the Western Regional Government; pressure from an enlightened populace and the personal foresight and experiences of some of the initiators of the scheme such as Chiefs Obafemi Awolowo and S.O. Awokoya because of their extensive travel overseas, among others. Yet, the influence of the missionary precedence of mass education cannot be underplayed.

Be that as it may, no sooner after the Western Region's example than the government of Eastern Nigeria, apparently drawing inspiration from the West's example, followed suit in $1957 .^{36}$ Northern Nigeria on the other hand, made no such efforts, thus continually lagging behind in terms of expanding her scope in Western education. This, as has been analyzed elsewhere, ${ }^{37}$ was principally the product of the inability of Christian Missions to penetrate that region due to reasons which, I believe, are not unconnected with the resilience of the Islamic religion which was too strongly footed here. That was coupled with a painful lack of foresight and initiative as well as an unimaginative local governmental education policy. For, even if one admits, as has been argued by a number of scholars, with convincing force, that the late response of the people of Northern Nigeria to Western education and their conservatism owe much to the British colonial policy, ${ }^{38}$ arguments which hold very much up to 1950 , how else does one explain the post- 


\section{Christian Missions and Evolution of Mass Education}

1950 educational developments? As indicated in an earlier study, ${ }^{39}$

From 1951 when Governor Macpherson introduced a new constitution, each regionally based political party existing then (the N.C.N.C. in the East, A.G. in the West and N.P.C. in the North) was empowered to raise the appropriate funds, and more importantly, had power to pass laws on education among other amenities.

In essence, therefore, the parties had been given the free hand to operate and became responsible for the growth of Western education in their respective regions. The Western Region's choice and introduction of Free Education which became fully operative from 1955, an epoch that had no precedence in the educational history of Nigeria until then, logically emanated from the established pattern of mass western educational development that had been flowering from the era of Christian missionary enterprise in the area. Missionary education went a long way in pushing Western Nigeria, and indeed the entire South, far ahead of Northern Nigeria. As had been demonstrated above, the venture infused a culture of mass literacy in the people. That giant stride in education has had a spill-over effect on the educational development of the country. For, it has set in motion a chain of educational advancement $-\mathrm{a}$ trend that helped to widen further the educational imbalance between Western Nigeria in particular and Southern Nigeria in general, and their Northern counterparts.

In 1966, the army took over the government of the Federal Republic of Nigeria. Since Western Nigeria was, as it still is, an integral part of the Federation, the military take-over 


\section{S. Ademola Ajayi}

obviously effected a chink in the armour of an epoch in the educational history of the region. However, as the culture of mass education had been created in, and imbibed by the citizenry of the area covered by the defunct Western region, that cultural awareness was never underplayed by any of the subsequent governments in order to win the support and popularity among the subjects. For instance, the military leaders of the region (later the states) between 1966 and 1979 never ignored the issue of mass education though it was modified. The setting up of the Taiwo Committee in $1968-$ two years after the military take-over - to review the primary education system in Western State of Nigeria, ${ }^{40}$ is an ample demonstration of the concern of the then military government for mass popular education.

Moreover, the commitment of the government to popular education explains why with the lift of the ban on political activities in 1978 and the concomitant ushering in of a civilian administration in Nigeria between 1979 and 1983, the mass education programme raised its head again and featured prominently among the cardinal programmes of the states that made up the defunct Western region. Interestingly enough the Second Republic National Party of Nigeria (N.P.N) which initially maintained a posture of apathy towards mass education had no option but to reverse its erstwhile stand on this when it took over the administration of Oyo State in October 1983. Ruling over a people among whom the culture of mass education had been firmly entrenched, the Party had no choice but to modify its erstwhile slogan and philosophy of "qualitative education" (which was then synonymous with education for a few) to that of a "free qualitative" or mass popular education. 


\section{Christian Missions and Evolution of Mass Education}

An equally significant development is the fact that with the termination of the civilian regime and party politics in 1983, the emergent military administrations in the states of Oyo (later Oyo and Osun), Ogun, Ondo (later Ondo and Ekiti), Lagos and Bendel (later Edo and Delta) states, areas covered by the old Western region, found it difficult to abolish the mass education system in its entirety. The trend is very much the same under the current civilian dispensation of Nigeria's Fourth Republic in the area. It should be stressed, however, that there have been some modifications both in scope and structure, for obvious economic and logistic reasons. But, the fact still remains that the root of mass education (even of the 1980 s and 1990s, up to the beginning of the twenty-first century), irrespective of whatever form it might have taken, cannot be divorced from the culture of mass literacy in this area, an idea or innovation whose antecedents are traceable to Christian missionary endeavours in Western Nigeria.

\section{Notes and References}

1. Western Nigeria is the area covered by the modern day Oyo, Ogun, Ondo, Osun, Ekiti, Lagos, Edo and Delta States. During the era of Provincial administration in the country, it consisted of eight provinces namely, Abeokuta, Benin, Colony (i.e. Lagos), Delta, Ibadan, Ijebu, Ondo and Oyo - all of which were collectively known as the 'Western Provinces'. 2. A. Babs Fafunwa, History of Education in Nigeria (London: George Allen \& Unwin, 1974) p. 74.

3. J. F. Ade Ajayi, Christian Missions in Nigeria, 1841-1891: The Making of a New Elite. (Burnt Mill, Harlow, Essex: Longman, 1965) p. 2.

4. Ibid. See also, C.P. Groves, The Planting of Christianity in Africa (London: Lutherworth Press, 1948) p. 58.

5. See, J.F. Ade Ajayi, Christian Missions in Nigeria, p. 3.

6. Ibid. pp. 8-9. 


\section{S. Ademola Ajayi}

7. The reader who may be interested in the advocacy of these Humanitarians and the philosophers of the Age of Reason will benefit immensely from the fairly comprehensive account in J.F. Ade Ajayi's Christian Missions, p. 8 ff.

8. The Yoruba people constitute the largest ethnic group, forming over $80 \%$ of the population of Western Nigeria.

9. A. Babs Fafunwa, History of Education in Nigeria, p. 77.

10. Otonti Nduka, Western Education and the Nigerian Cultural Background (Ibadan: University Press Ltd., 1982) p. 10.

11. This was published in Washington by the Smithsonian Institute.

12. J.F. Ade Ajayi, Christian Missions, p. 159.

13. Henry Townsend: Letter to Rev. Henry Venn, 4 May, 1860 in C.M.S. CA2/085

14. See S.A. Ajayi, "The Development of Free Education in Western Nigeria, 1951-1966: A Historical Analysis" (Unpublished M.A. Dissertation, Department of History, University of Ibadan, 1984), .p.9

15. Relevant Studies on the above subject include the following: A. Babs Fafunwa, History of Education in Nigeria; C.O. Taiwo, The Nigerian Education System: Past, Present \& Future (Lagos: Nelson, 1980); Segun Adesina, Planning and Educational Development in Nigeria, (Lagos: Educational Industries Nigeria Ltd. 1977); Otonti Nduka, Western Education and the Nigerian Cultural Background: See also S.O. Osoba and A. Fajana, "Educational and Social Development during the Twentieth Century: in O. Ikime (ed.) Groundwork of Nigerian History, (Ibadan: Heinemann, 1980); A. Fajana, Education in Nigeria, 1842-1939: An Historical Analysis (Ikeja: Longman, 1978).

16. Lekan Oyedeji, U.P.E. in Nigeria: Its Implications for National Development (Lagos: Lagos University Press, 1973), p. 12.

17. See the Editorial of Lagos Times of 26 January, 1881 captioned "Education in the Colony".

18. A. Fajana, Education in Nigeria, p. 92. See also, A. Babs Fafunwa, History of Education, p. 93.

19. S.O. Osoba and A. Fajana, "Education and Social Development..." in O. Ikime (ed.) Groundwork of Nigerian History p. 572.

20. See section 92 of the Nigerian (Constitution) Order in Council, 1951. cited in A. Fajana, Education in Nigeria, p. 235. 


\section{Christian Missions and Evolution of Mass Education}

21. He was then the Western Region Minister for Local Government while at the same time acting as unofficial leader of government business.

22. See O. Awolowo, Awo: The Autobiography of Chief Obafemi Awolowo (Cambridge: Cambridge University Press, 1960) p. 263.

23. Proposal for an Education Policy for the Western Region, Nigeria, Laid on the Tables of the Western Regional Legislature by the Minister for education, Western Region, July 1952 ((Ibadan: Government Printer, 1952), pp. 1-36.

24. Western House of Assembly Debates: Official Report (First Session) $30^{\text {th }}$ July, 1952 (Ibadan: Government Printer, 1953), p. 464.

25. A. Babs Fafunwa, History of Education in Nigeria, p. 168.

26. A. Fajana, Education in Nigeria, p. 238.

27. C.O. Taiwo, The Nigerian Education System, p. 116.

28. Ibid.

29. After the creation of the Mid-West region in 1963, the Ministry of Economic planning and Community Development (Statistics Division) prepared a new statistics of schools in the Western region. For details see, Western Nigeria Annual Abstract of Education Statistics 1961, 1963 and 1964. See also, S.A. Ajayi, "The Development of Free Education in Western Nigeria..." p. 48

30. Awokoya's Proposal for an Education Policy, p. 5 cf. a similar argument by the Minister himself in Western House of Assembly Debates, 30 July, 1952, p. 462.

31. Awokoya, Proposal for an Education Policy, p. 17 .

32. Ibid.

33. The underestimation by government officials vis-à-vis the overenrolment of pupils during the first few years of the Free Education scheme posed a lot of problems. The reader who may be interested in details of some of these problems would benefit from this writer's fairly comprehensive discussion in S.A. Ajayi, "The Development of Free Education in Western Nigeria..” pp. 106-141..

34. A. Babs Fafunwa, History of Education, p. 168..

35. See S.A. Ajayi, "The Genesis of Free Education in Western Nigeria, 1951-1966" in Nigerian Journal of History Teachers, Vol. I (April 1992), pp. $150-163$.

36. See the Eastern Region Debates, May 16, 1955 (Enugu, Government Printer, 1955), pp. 78-79. 


\section{S. Ademola Ajayi}

37. S. A. Ajayi, "The Origin and Growth of Baptist Mission Work in Yorubaland, 1850-1960", (Ph.D. Thesis in History, University of Ibadan, 1992), p. 430.

38. See for example, Saad Abubakar, "The Northern Provinces under Colonial Rule: 1900-1959" in Obaro Ikime (ed.) Groundwork of Nigerian History, pp. 473-476; Cf. Obaro Ikime, In Search of Nigerians: Changing Patterns of Inter-Group Relations in an Evolving Nation State. Presidential Inaugural Lecture delivered at the $30^{\text {th }}$ Congress of the Historical Society of Nigeria, at the University of Nigeria, Nsukka, on 1 May, 1985, pp. 14-16.

39. S.A. Ajayi, "The Development of Free Education in Western Nigeria..." p. 151

40. For details of the Committee's terms of reference and recommendations respectively, see C.O. Taiwo (Chairman) Report of the Committee on the Review of the Primary Education System in the Western State of Nigeria (Ibadan: Government Printer 1968). 